\title{
C-Reactive Protein and Fibrinogen as Indicators of Systemic Inflammatory Response in Patients Undergoing VATS and Conventional Pulmonary Lobectomy
}

\author{
Ints Silins*,**, Maris Apsvalks*, Arta Sirgeda*, Aigars Petersons**, Alvils Krams*** \\ *Department of Thoracic Surgery, Centre of Tuberculosis and Lung Diseases, Riga East University Hospital, Latvia \\ **Riga Stradins University, Latvia \\ ***Medical Faculty of Latvian University, Latvia
}

\begin{abstract}
Summary
Introduction. There is still ongoing discussion about superiority of video-assisted thoracoscopic surgery or VATS approach for performing lobectomy over conventional pulmonary lobectomy performed by open thoracotomy for the treatment of non-small cell lung cancer at an early stage.

Aim of the study. This encouraged us to conduct a prospective study for evaluation and comparison of the systemic inflammatory response by using these two approaches.

Materials and methods. We have conducted a prospective study for evaluation of C-reactive protein and Fibrinogen as indicators of systemic inflammatory response during early postoperative course. Surgery was prospectively randomised in two groups: 15 patients underwent VATS lobectomy and 15 patients underwent conventional open lobectomy. Blood samples were taken preoperatively, 24 and 72 hours after operation, on the day of drain removal, and 1 and 9 days after the drain removal.

Results. Surgery caused systemic inflammatory response in both groups. The increase in CRP was notably higher in OL group in all measurements except preoperative $(p<0,05)$. The increase in Fibrinogen concentrations was also higher in OL group but statistical significance $(p<0,05)$ was reached only in day of drain removal.

Conclusions. VATS approach caused reduced systemic inflammatory response compared with conventional open thoracotomy approach and was also associated with lesser postoperative pain as duration of chest drains and total amount of drained effusion is significantly smaller.
\end{abstract}

Key words: VATS; lobectomy; lung cancer; systemic inflammatory response.

\section{INTRODUCTION}

Although first video-assisted dissectional pulmonary lobectomy was performed more than two decades ago (10) and this technique is established as suitable and appropriate for treatment of early stage non-small cell lung cancer $(5,6,15,17,20,22,23)$, there is still ongoing discussion about superiority of this approach over conventional pulmonary lobectomy performed by open thoracotomy approach $(1,7,22,24,25)$.

We started VATS lobectomy in 2006 and observed surgical results and early postoperative outcomes at least equal to open thoracotomy approach in retrospective study we performed (13). This encouraged us to conduct a prospective study for evaluation and comparison of the systemic inflammatory response by using these two approaches.

\section{AIM OF THE STUDY}

The aim of our study is to compare systemic inflammatory response in early-stage non small cell lung cancer patients undergoing radical surgical intervention - pulmonary lobectomy with mediastinal nodal dissection by both minimally invasive and conventional approach.

\section{MATERIALS AND METHODS}

We have conducted prospective study to evaluate such systemic inflammatory response parameters as C-Reactive Protein (CRP) and Fibrinogen during early postoperative course comparing two approaches VATS or video-assisted thoracoscopic surgery lobectomy and conventional or open thoracotomy lobectomy. Our study included 30 patients with early-stage (I-II) NSCLC who underwent anatomical resection - pulmonary lobectomy with mediastinal nodal dissection. All patients underwent surgery in the Department of Thoracic Surgery at the Centre of Tuberculosis and Lung Diseases of the Riga East University Hospital between March 2011 and May 2013. Surgery was prospectively randomised in two groups: 15 patients underwent fully thoracoscopic VATS lobectomy without any rib spreading manoeuvre via one utility incision up to $6 \mathrm{~cm}$ and 2 additional ports (VATS-L group); 15 patients underwent conventional open lobectomy by lateral thoracotomy approach via incision of $15-25 \mathrm{~cm}$ with applying of rib spreader and 1-2 chest drains (OL group). We evaluated patient demographics, tumour histology and stage, type and duration of surgery, as 
well as drain management results - duration of chest drain and amount of postoperative pleural effusion. Blood samples were taken for CRP and Fibrinogen analysis in both groups preoperatively, 24 and 72 hours after operation, on the day of drain removal, and 1 and 9 days after the drain removal. For evaluation of data distribution Kolmogorov-Smirnoff test and/ or diagnostic histograms were used. In each group mean parameters and standard deviations were calculated. In comparison of mean parameters in different time periods in postoperative course in each group and between two groups parametrical (paired and unpaired t-test) or non-parametrical (Wilcoxon or Mann-Witney test) tests were used depending of data distribution.

\section{RESULTS}

Patients in both groups had similar demographics as it is shown in Table 1. There was no difference found neither according to patient age, gender, tumour histology and stage nor type of performed lobectomy. Mean age was 58,4 years in VATS-L group and 59,6 years OL group. Adenocarcinoma was most common tumour type in both groups. All types of lobectomies were performed in both groups. Duration of operation was slightly longer in VATS-L group (mean - 141 minutes) compared to OL group (mean - 124 minutes), but difference was not statistically significant.

There were clear advantages in VATS-L group over OL group according to drain management and all these parameters reached statistical significance as it is illustrated in Table No.2. Drains could be removed quicker in VATS-L group on 3,5 (mean) postoperative day versus 4,7 (mean) postoperative day in OL group. Drained volumes of pleural effusion were smaller both in first three postoperative days and in total in VATS-L group $(500 \mathrm{ml}$ and $650 \mathrm{ml})$ in comparison with OL group (1200 ml and $1500 \mathrm{ml}$ ) accordingly. Prolonged air-leak more than 7 days were observed in one occasion in each group, no other major complications were observed.

Surgery caused systemic inflammatory response as increases in plasma CRP and Fibrinogen concentrations were observed in both groups after surgery. The increase in CRP was notably higher in OL group compared with VATS-L group in all measurements except preoperative (were no statistically significant difference was found) and all reached statistical significance $(p<0,05$ in all measurements except a day after drain removal where $0,05<\mathrm{p}<0,1)$ as it is illustrated in Graph No.1. In VATS-L group elevation of CRP in postoperative course was slower and reached stable flat-like status before slowing down, whereas in OL group elevation of CRP was much quicker and reached peak in the third postoperative day before dropping back towards preoperative measurement but not reaching it. The increase in Fibrinogen concentrations was also higher in OL group but statistical significance $(p<0,05)$ was reached only in day of drain removal as it is shown in Graph No.2.

\section{DISCUSSION}

Currently VATS lobectomy is accepted as feasible and appropriate procedure for selected patients with early-stage non-small cell lung cancer and several large studies have demonstrated that VATS lobectomy is not only safe procedure, but that even provides better functional recovery and oncological efficacy is similar to that what is achieved with conventional thoracotomy $(5,10,16,22-24)$.

VATS approach provide much better results with less pain and quicker recovery to normal activity during early postoperative period compared with conventional open thoracotomy approach $(4,7-9,12)$. But despite that early recovery is fast, there is not so big difference between two approaches according to postoperative pain in later postoperative period starting from three month after surgery. Preservation of lung function is not dependent on surgical approach but rather on the amount of remaining lung (3).

There have been several studies exploring acute phase inflammatory and immunologic response to surgical trauma and cytokine network plays important role, but most of them are devoted to different laparoscopic procedures compared with their counterpart open conventional procedures showing decreased release of cytokines. But few of these studies $(2,21,25)$ confirmed reduced postoperative release of both proinflammatory and anti-inflammatory cytokines in VATS lobectomy compared to an open approach.

Other authors also like we experienced some difficulties and limitations in the randomization in presence of the choice of VATS approach, but anyway achieved to form two groups comparable in their demographics as well as in their pathology. They have also understood that not only systemic but also local cytokine responses in pleural cavity and lung tissue may play important role and need to be investigated (25).

There are data available that immunologic response is characterized not only by release of cytokines and inflammatory mediators but also by release of acute phase protein and adverse disturbances in immune cell function. The usage of minimally invasive approach is associated not only with reduced cytokine response but also with reduction of corresponding acute phase protein CRP levels $(2,21)$. Our data also showed slower and less expressed elevation of CRP in early postoperative period when applying VATS approach for performing lobectomy in comparison with conventional open thoracotomy approach.

Other factors predicting postoperative course and pulmonary complications as preoperative serum fibrinogen (14) and lactate dehidrogenase $(18,19)$ levels have been investigated. Our finding of reduced fibrinogen elevation in early postoperative period after VATS lobectomy could also reflect that VATS approach causes less systemic response to surgery compared to open thoracotomy approach. 


\section{CONCLUSIONS}

Although the clinical significance of this study is not fully elucid, we have shown that VATS approach causes reduced systemic inflammatory response compared with conventional open approach. This finding may be associated with lesser implications on patient immunological status and tumour immunosurveillance what is extremely important for lung cancer patients. VATS technique was also associated with lesser postoperative pain and local reaction as duration of chest drains and amount of drained postoperative pleural effusion is significantly reduced in comparison with conventional open approach and all this lead to faster recovery in early postoperative period. Elucidation of the mechanisms responsible for these clinical benefits may have strong implications on the future development of lung cancer management strategies.

\section{Conflict of interest: None}

\section{REFERENCES}

1. Cattaneo SM, Park BJ, Wilton AS, Seshan VE, Bains MS, Downey RJ, Flores RM, Rizk $\mathrm{N}$, Rusch VW. Use of video-assisted thoracic surgery for lobectomy in elderly results in fewer complications // Ann Thorac Surg, 2008; 85:231235

2. Craig SR, Leaver HA, Yap PL, Pugh GC, Walker WS. Acute responses following minimal access and conventional thoracic surgery // Eur J Cardiothorac Surg, 2001; 20:455-463

3. Jheon S, Yang HC, Cho SC. Video-assisted thoracic surgery for lung cancer // Gen Thorac Cardiovasc Surg, 2012; 60:255-260

4. Kaseda S, Aoki T, Hangai N, Shimizu K. Better pulmonary function and prognosis with videoassisted thoracic surgery than with thoracotomy // Ann Thorac Surg, 2000; 70:1644-1646

5. McKenna RJ, Houck W, Fuller CB. Video-assisted thoracic surgery lobectomy: experience with 1,100 cases // Ann ThoracSurg, 2006; 81:421-425

6. McKenna RJ, Wolf RK, Brenner $M$, Fischel RJ, Wurning P. Is lobectomy by video-assisted thoracic surgery an adequate cancer operation? // Ann Thorac Surg, 1998; 66:1903-1908

7. Nagahiro I, Andou A, Aoe M, Sano Y, Date H, Shimizu N. Pulmonary function, postoperative pain, and serum cytokine level after lobectomy: a comparison of VATS and conventional procedure// Ann Thorac Surg, 2001; 72:362-365

8. Nakata M, Saeki H, Yokoyama N, Kurita A, Takiyama W, Takashima S. Pulmonary function after lobectomy: video-assisted thoracic surgery versus thoracotomy // Ann Thorac Surg, 2000; 70:938-941

9. Nicastri DG, Wisnivesky JP, Litle VR, Yun J, Chin C, Dembitzer FR, Swanson SJ. Thoracoscopic lobectomy: report on safety, discharge independence, pain, and chemotherapy tolerance // J Thorac Cardiovasc Surg, 2008; 135:642-647
10. Paul S, Altorki NK, Sheng S, Lee PC, Harpole $\mathrm{DH}$, Onaitis MW, et al. Thoracoscopic lobectomy associated with lower morbidity than open lobectomy: a propensity-matched analysis from STS database // J Thorac Cardiovasc Surg, 2010; 139:366-378

11. Roviaro G, Rebuffat C, Varoli FC, Mariani C, Maciocco M. Videoendoscopic pulmonary lobectomy for cancer // Surg Laparosc Endosc, 1992; 2:244-247

12. Shaw JP, Dembitzer FR, Wisnivesky JP, Litle VR, Weiser TS, Yun J, et al. Video-assisted thoracoscopic lobectomy:state of the art and future directions // Ann Thorac Surg, 2008; 85:S705-S709

13. Silins I, Apsvalks M, Sirgeda A. VATS Lobectomy: a Report of Our Initial Experience // Acta Chirurgica Latviensis, 2008; 8:64-70

14. Song SW, Lee HS, Kim MS, Nam BH, Zo JI. Preoperative serum fibrinogen level predicts postoperative pulmonary complications after lung cancer resection // Ann Thorac Surg 2006; 81:19741981

15. Sugi K, Kaneda Y, Esato K. Video-assisted thoracoscopic lobectomy achieves a satisfactory long-term prognosis in patients with clinical stage IA lung cancer // World J Surg, 2000; 24:2731

16. Swanson SJ, Herndon JE, D`Amico TA. Videoassistedthoracic surgery lobectomy: report of CALGB 39802 - a prospective, multi-institution feasibility study // J Clin Oncol 2007; 25:4993-4997

17. Thomas P, Dodolli C, Yena S, Thirion X, Sebag F, Fuentes P, Giudicelli R. VATS is an adequate oncological operation for stage I non-small cell lung cancer // Eur J Cardiothorac Surg, 2002; 21:1094-1099

18. Turna A, Solak O, Cetinkaya E, Kilicgun A, Metin M, Sayar A, Gurses A. Lactate dehydrogenase levels predict pulmonary morbidity after lung resection for non-small cell lung cancer // Eur J Cardiothorac Surg 2004; 26:483-487

19. Uramoto $H$, Naknishi $R$, Fujino $Y$, Imoto $H$, Takenoyama M, Yoshimatsu T, Oyama T, Osaki T, Yasumoto K. Prediction of pulmonary complications after lobectomy in patients with non-small cell lung cancer // Thorax, 2001; 56:5961

20. Walker WS, Codispoti M, Soon SY, Stamenkovic S, Carnochan F, Pugh G. Long-term outcomes following VATS lobectomy for non-small cell bronchogenic carcinoma // Eur J Cardiothorac Surg, 2003; 23:397-402

21. Walker WS, Leaver HA. Immunologic and stress responses following video-assisted thoracic surgery and open pulmonary lobectomy in early stage lung cancer. // Thor Surg Clin 2007; 17:241-249

22. Whitson BA, Andrade RS, Boettcher A, Bardales R, Kratzke RA, Dahlberg PS, Maddaus MA. Video-assisted thoracoscopic surgery is more favourable than thoracotomy of clinical stage I 
non-small cell lung cancer // Ann Thorac Surg, 2007; 83:1965-1970

23. Whitson BA, Groth SS, Duval SJ, Swanson SJ, Maddaus MA. Surgery for early-stage non-small cell lung cancer: a systematic review of the videoassisted thoracoscopic surgery versus thoracotomy approaches to lobectomy // Ann Thorac Surg, 2008; 86:2008-2016

24. Yan TD, Black D, Bannon PG, McCaughan BC. Systematic review and meta-analysis of randomized and non-randomized trials on safety and efficacy of video-assisted thoracic surgery lobectomy for early-stage non-small-cell lung cancer // J Clin Oncol, 2009; 27:2553-2562

25. Yim APC, Wan S, Lee TW, Arifi AA. VATS Lobectomy reduces cytokine responses compared with Conventional surgery // Ann Thorac Surg 2000; 70:243-247

\section{Address:}

Ints Silins

Department of Thoracic Surgery

Centre of Tuberculosis and Lung Diseases

Riga East Clinical University Hospital

Upeslejas, Stopinu novads, Latvia LV-2118

E-mail: ints.silins@aslimnica.lv

Table 1. Clinical characteristics of patients

\begin{tabular}{|c|c|c|}
\hline & $\begin{array}{l}\text { VATS-L } \\
\text { group } \\
(\mathrm{N}=15)\end{array}$ & $\begin{array}{l}\text { OL group } \\
(\mathrm{N}=15)\end{array}$ \\
\hline Gender: Male/Female & $11 / 4$ & $9 / 6$ \\
\hline Age $($ mean $\pm S D)$ & $58,4 \pm 10,7$ & $59,6 \pm 9,4^{\mathrm{NS}}$ \\
\hline $\begin{array}{l}\text { Tumour histology: } \\
\text { Squamous cell lung cancer } \\
\text { Adenocarcinoma } \\
\text { Malignant carcinoid }\end{array}$ & $\begin{array}{c}3 \\
10 \\
2 \\
\end{array}$ & $\begin{array}{l}5 \\
9 \\
1\end{array}$ \\
\hline $\begin{array}{l}\text { Tumour stage: } \\
\text { T1AN0M0 } \\
\text { T1BN0M0 } \\
\text { T2AN0M0 } \\
\text { T2BN0M0 } \\
\text { T1AN1M0 } \\
\text { T1BN1M0 } \\
\text { T2BN1M0 }\end{array}$ & $\begin{array}{l}7 \\
5 \\
2 \\
1\end{array}$ & $\begin{array}{l}7 \\
2 \\
2 \\
2 \\
1 \\
1\end{array}$ \\
\hline $\begin{array}{l}\text { Type of lobectomy: } \\
\text { RUL } \\
\text { RLL } \\
\text { LUL } \\
\text { LLL }\end{array}$ & $\begin{array}{l}5 \\
3 \\
2 \\
5\end{array}$ & $\begin{array}{l}5 \\
2 \\
7 \\
1\end{array}$ \\
\hline $\begin{array}{l}\text { Length of operating time in } \\
\text { minutes (mean } \pm S D \text { ) }\end{array}$ & $141 \pm 34$ & $124 \pm 21^{\mathrm{NS}}$ \\
\hline
\end{tabular}

NS $p>0,1$; RUL - right upper lobectomy; RLL - right lower lobectomy; LUL - left upper lobectomy; LLL left lower lobectomy
Table 2. Data of drain management

\begin{tabular}{|l|l|l|}
\hline & $\begin{array}{l}\text { VATS-L group } \\
(\mathrm{N}=15)\end{array}$ & $\begin{array}{l}\text { OL group } \\
(\mathrm{N}=15)\end{array}$ \\
\hline $\begin{array}{l}\text { Drain removal day } \\
(\text { mean } \pm \text { SD) }\end{array}$ & $3,5 \pm 2,3$ & $4,7 \pm 1,5 * *$ \\
\hline $\begin{array}{l}\text { Drained volume in } \\
\text { ml until 3 } \\
(\text { mean } \pm \text { SD })\end{array}$ & $498 \pm 206$ & $1178 \pm 291 * * *$ \\
\hline $\begin{array}{l}\text { Total drained volume } \\
\text { in ml (mean } \pm \text { SD) }\end{array}$ & $644 \pm 436$ & $1499 \pm 530 * * *$ \\
\hline
\end{tabular}

$* * \mathrm{p}<0,05 ; * * * \mathrm{p}<0,001$

Graph.1. Dynamics of CRP in plasma (mg/L) during postoperative course

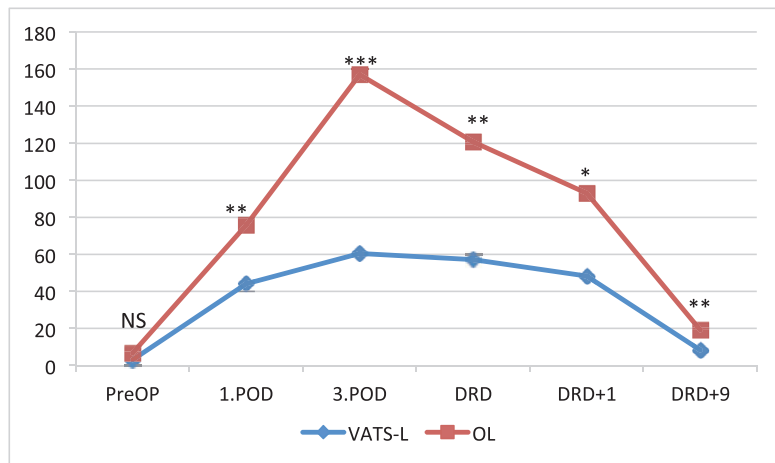

NS $\mathrm{p}>0,1 ; * 0,05<\mathrm{p}<0,1 ; * * \mathrm{p}<0,05 ; * * * \mathrm{p}<0,01$; PreOP preoperative day; POD - postoperative day; DRD drain removal day

Graph. 2. Dynamics of Fibrinogen in plasma $(\mathrm{g} / \mathrm{L})$ during postoperative course

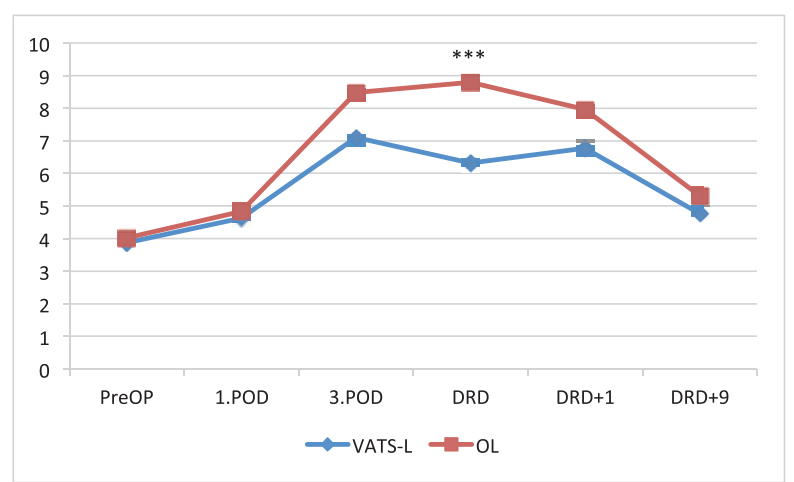

*** $\mathrm{p}<0,01$; PreOP - preoperative day; POD postoperative day; DRD - drain removal day 